ПАЦКАН В.В.

\title{
ФУНКЦІЇ РАХУНКОВОЇ ПАЛАТИ ЯК ВИЩОГО ОРГАНУ АУДИТУ УКРАЇНИ
}

Мета статті - охарактеризувати функції Рахункової палати як вищого органу аудиту України. Сформульовано визначення поняття «функції Рахункової палати як вищого органу аудиту України». Охарактеризовано окремі функції Рахункової палати як вищого органу аудиту України. Аудит ефективності передбачає встановлення фактичного стану справ і надання оцінки щодо своєчасності та повноти бюджетних надходжень, продуктивності, результативності, економності використання бюджетних коштів їхніми розпорядниками й одержувачами, законності, своєчасності та повноти прийняття управлінських рішень учасниками бюджетного процесу, стану внутрішнього контролю розпорядників бюджетних коштів. Важливе значення для ефективного здійснення заходів державного зовнішнього фінансового контролю (аудиту) мають також контрольні групи Рахункової палати. Член Рахункової палати для здійснення заходів державного зовнішнього фінансового контролю (аудиту) створює контрольні групи, призначає їхніх керівників і заступників керівників або очолює такі групи, залучаючи у разі необхідності посадових осіб різних департаментів і територіальних підрозділів, а також координує роботу контрольних груп щодо здійснення заходів державного зовнішнього фінансового контролю (аудиту). Зроблено висновок, що поняття «функції Рахункової палати як вищого органу аудиту України» можна визначити як основні напрями впливу Рахункової палати як вищого органу аудиту України на поведінку суб'єктів правовідносин із метою організації діяльності та здійснення повноважень Рахункової палати. Виокремлено такі функції Рахункової палати: здійснення заходів державного зовнішнього фінансового контролю (аудиту), міжнародне співробітництво, внутрішній контроль у Рахунковій палаті. Перспективи подальших наукових досліджень у цьому напрямі полягають у порівняльно-правовому аналізі функцій Рахункової палати та вищих органів аудиту країн-членів СС, принципів діяльності Рахункової палати, адміністративно-правового статусу Рахункової палати.

Ключові слова: Рахункова палата, вищий орган аудиту, державна влада, аудит, функиї, адміністративна реформа.

The purpose of the article is to characterize the issues of the functions of the Accounting Chamber as the highest audit body of Ukraine. The definition of the concept "functions of the Accounting Chamber as the highest audit body of Ukraine" is formulated. Some functions of the Accounting Chamber as the highest audit body of Ukraine are described. Performance audit involves establishing the actual state of affairs and assessing the timeliness and completeness of budget revenues, productivity, efficiency, economy of use of budget funds by their managers and recipients, legality, timeliness and completeness of management decisions by participants in the budget process, the state of internal control of budget managers. The control groups of the Accounting Chamber are also important for the effective implementation of measures of state external financial control (audit). A member of the Accounting Chamber establishes control groups for the implementation of measures of state external financial control (audit), appoints heads and deputy heads of such groups or heads such groups, involving officials of various departments and territorial divisions, as well as coordinates the work of control groups state external financial control (audit). It is concluded that the concept of "functions of the Accounting Chamber as the highest audit body of Ukraine" can be defined as the main areas of influence of the Accounting Chamber as the highest audit body of Ukraine on the behavior of

(C) ПАЦКАН В.В. - здобувач кафедри адміністративного, фінансового, інформаційного права (ДВНЗ «Ужгородський національний університет») 
legal entities to organize activities and exercise the powers of the Accounting Chamber. The following functions of the Accounting Chamber are singled out: implementation of measures of state external financial control (audit), international cooperation, internal control in the Accounting Chamber. There are prospects for further research in this area, in particular, on: comparative legal analysis of the functions of the Accounting Chamber and the highest audit bodies of EU member states; principles of activity of the Accounting Chamber; administrative and legal status of the Accounting Chamber.

Key words: Accounting Chamber, Supreme Audit Institution, the state government, audit, functions, administrative reform.

Вступ. У контексті розвитку України як правової та демократичної держави, євроінтеграції України, розвитку Рахункової палати як вищого органу аудиту України, запобігання і протидії корупції в Україні, адміністративної реформи важливим є дослідження функцій Рахункової палати як вищого органу аудиту України, що має практичне значення для подальшого вдосконалення адміністративного законодавства України, а також правозастосовної практики у цій сфері та сприяє розвитку науки адміністративного права.

Постановка завдання. Мета статті - охарактеризувати функції Рахункової палати як вищого органу аудиту України.

Завдання статті: сформулювати визначення поняття «функції Рахункової палати як вищого органу аудиту України» й охарактеризувати вказані функції.

Окремі аспекти зазначеної проблематики були предметом дослідження сучасних науковців, зокрема О. Гриценка, О. Койчевої, О. Ніконової, Н. Обушної, Л. Савченко.

Результати дослідження. Важливе значення 3-поміж засад адміністративно-правового статусу Рахункової палати як вищого органу аудиту України мають функції Рахункової палати.

У Резолюції від 19 грудня 2014 р. № 69/228 щодо сприяння діяльності вищих органів державного аудиту Генеральна асамблея ООН чітко резюмувала, що вищі органи аудиту можуть об'єктивно та результативно виконувати свої функції лише в тому разі, якщо вони незалежні від структур, які перевіряються ними, і захищені від зовнішнього впливу [1].

Функції є основним елементом змісту діяльності будь-якого органу і реалізуються через покладені на нього повноваження, головним моментом у визначенні та забезпеченні дієвості механізмів реалізації функцій Рахункової палати має стати встановлення відповідності повноважень Рахункової палати ії функціям [2, с. 106].

Л.А. Савченко до функцій Рахункової палати відносить контрольну, експертно-аналітичну, інформаційну, консультативну [3, с. 301].

О.І. Гриценко функції Рахункової палати розглядає через забезпечення відповідними повноваженнями та виділяє такі: прогнозування, планування, регулювання, організації, координації, обліку й аналізу інформації, аналітичну, експертну, консультативну та контролю (контрольно-ревізійну функцію) [4, с. 37-52].

Отже, функції Рахункової палати - це основні напрями впливу Рахункової палати як вищого органу аудиту України на поведінку суб'єктів правовідносин із метою організації діяльності та здійснення повноважень Рахункової палати. Можна виокремити такі функції: здійснення заходів державного зовнішнього фінансового контролю (аудиту), міжнародне співробітництво, внутрішній контроль у Рахунковій палаті.

1.3дійснення заходів державного зовнішнього фінансового контролю (аудиту).

Згідно зі ст. 4 Закону України «Про Рахункову палату» [5] повноваження, покладені на Рахункову палату Конституцією України, здійснюються через провадження заходів державного зовнішнього фінансового контролю (аудиту).

А.Г. Андрєєв зазначає, що фінансовий контроль важче поставити в незалежне становище, оскільки це контроль дії не будь-якої окремої частини адміністративного апарату, але всієї фінансово-господарської діяльності органів управління загалом [6, с. 64].

Державний зовнішній фінансовий контроль (аудит) забезпечується Рахунковою палатою шляхом здійснення фінансового аудиту, аудиту ефективності, експертизи, аналізу та інших контрольних заходів.

Фінансовий аудит полягає у перевірці, аналізі й оцінці правильності ведення, повноти обліку і достовірності звітності щодо надходжень і витрат бюджету, встановленні фактичного стану справ щодо цільового використання бюджетних коштів, дотримання законодавства при здійсненні операцій із бюджетними коштами. 
Аудит ефективності передбачає встановлення фактичного стану справ і надання оцінки щодо своєчасності та повноти бюджетних надходжень, продуктивності, результативності, економності використання бюджетних коштів їхніми розпорядниками й одержувачами, законності, своєчасності та повноти прийняття управлінських рішень учасниками бюджетного процесу, стану внутрішнього контролю розпорядників бюджетних коштів.

Оцінка продуктивності використання бюджетних коштів передбачає встановлення співвідношення між результатами діяльності розпорядника й одержувача бюджетних коштів і використаними для досягнення таких результатів коштами бюджету.

Оцінка результативності використання бюджетних коштів передбачає встановлення ступеня відповідності фактичних результатів діяльності розпорядника й одержувача бюджетних коштів запланованим результатам.

Оцінка економності використання бюджетних коштів передбачає встановлення стану досягнення розпорядником та одержувачем таких коштів запланованих результатів за рахунок використання мінімального обсягу бюджетних коштів або досягнення максимального результату за використання визначеного бюджетом обсягу коштів.

Враховуючи вищенаведене, з метою забезпечення дотримання законності й ефективності використання бюджетних коштів надзвичайно важливо забезпечити ефективне провадження заходів державного зовнішнього фінансового контролю (аудиту) Рахунковою палатою.

Основним нормативно-правовим актом, що регламентує порядок здійснення заходів державного зовнішнього фінансового контролю (аудиту) Рахунковою палатою, є Регламент Рахункової палати [7], затверджений рішенням Рахункової палати від 28 серпня 2018 р. № 22-7. Порядок здійснення заходів державного зовнішнього фінансового контролю (аудиту) Рахунковою палатою розглянемо нижче.

Згідно із п. 29.1. цього Регламенту підставою для надання членом Рахункової палати департаменту (департаментам) та / або територіальному підрозділу (підрозділам) доручення для виконання повноважень члена Рахункової палати та здійснення заходу державного зовнішнього фінансового контролю (аудиту) є план роботи Рахункової палати або рішення Рахункової палати про здійснення позапланового заходу державного зовнішнього фінансового контролю (аудиту).

Підставою для здійснення департаментом (департаментами) та / або територіальним підрозділом (підрозділами) підготовки та проведення заходів державного зовнішнього фінансового контролю (аудиту) є підписане членом Рахункової палати доручення для виконання повноважень члена Рахункової палати та забезпечення здійснення заходу державного зовнішнього фінансового контролю (аудиту). У дорученні для виконання повноважень члена Рахункової палати та забезпечення здійснення департаментом (департаментами) та / або територіальним підрозділом (підрозділами) заходу державного зовнішнього фінансового контролю (аудиту) зазначаються підстава, вимоги до складу контрольної групи, строки здійснення, а також терміни подання підготовлених за результатами такого заходу матеріалів члену Рахункової палати.

Доручення члена Рахункової палати для виконання його повноважень і забезпечення здійснення департаментом (департаментами) та / або територіальним підрозділом (підрозділами) заходу державного зовнішнього фінансового контролю (аудиту) $є$ підставою для проведення посадовими особами департаменту (департаментів) та / або територіального підрозділу (підрозділів) попереднього вивчення об'єктів і предмета аудиту, підготовки проекту програми (стратегії, плану) та фактичного здійснення заходу державного зовнішнього фінансового контролю (аудиту).

Захід державного зовнішнього фінансового контролю (аудиту) проводиться відповідно до програми (стратегії, плану). Проект програми (стратегії, плану) готується посадовими особами департаменту, до повноважень яких належить здійснення заходу державного зовнішнього фінансового контролю (аудиту) згідно із закріпленими напрямами його діяльності на підставі плану роботи Рахункової палати чи рішення про здійснення позапланового заходу державного зовнішнього фінансового контролю (аудиту), а також відповідного доручення члена Рахункової палати, наданого департаменту та / або територіальному підрозділу.

Перед складанням програми (стратегії, плану) заходу державного зовнішнього фінансового контролю (аудиту) член Рахункової палати, відповідальний за його проведення, організовує попереднє вивчення його об'єктів і предмета. Відповідні запити щодо отримання інформації, яка стосується об'єкта і предмета заходу державного зовнішнього фінансового контролю (аудиту), підписує член Рахункової палати, відповідальний за його проведення.

Підготовлений проект програми (стратегії, плану) опрацьовується і погоджується зі структурними підрозділами апарату Рахункової палати, відповідальними за питання правового 
забезпечення та за питання аналітики, методології та контролю якості, а також за необхідності з іншими структурними підрозділами, у разі залучення їх до відповідного заходу державного зовнішнього фінансового контролю (аудиту).

Підставою для здійснення заходу державного зовнішнього фінансового контролю (аудиту) на визначених Програмою контрольного заходу об’єктах контролю $є$ підписане членом Рахункової палати доручення. У дорученні на здійснення заходу державного зовнішнього фінансового контролю (аудиту) на визначеному об'єкті контролю зазначаються підстава, мета, предмет, а також строк здійснення заходу державного зовнішнього фінансового контролю (аудиту), ііi керівник, заступник керівника та склад контрольної групи щодо такого об'єкта контролю.

Важливе значення для ефективного здійснення заходів державного зовнішнього фінансового контролю (аудиту) мають також контрольні групи Рахункової палати. Член Рахункової палати для здійснення заходів державного зовнішнього фінансового контролю (аудиту) створює контрольні групи, призначає їхніх керівників і заступників керівників або очолює такі групи, залучаючи у разі необхідності посадових осіб різних департаментів і територіальних підрозділів, а також координує роботу контрольних груп щодо здійснення заходів державного зовнішнього фінансового контролю (аудиту).

Склад контрольної групи для проведення затвердженого планом роботи Рахункової палати заходу державного зовнішнього фінансового контролю (аудиту) визначається членом Рахункової палати у програмі контрольного заходу. Керівником контрольної групи заходу державного зовнішнього фінансового контролю (аудиту) та керівником контрольної групи на окремому об'єкті аудиту призначається посадова особа департаменту або територіального підрозділу, професійна компетентність якої підтверджена участю у проведенні не менше десяти заходів державного зовнішнього фінансового контролю (аудиту), звіти про результати яких затверджені рішеннями Рахункової палати. Склад контрольних груп, які формуються за окремими затвердженими у програмі контрольного заходу об' єктами, визначається у дорученнях на виконання заходу державного зовнішнього фінансового контролю (аудиту) на об'єктах контролю, що підписуються членом Рахункової палати, відповідальним за здійснення контрольного заходу.

2. Міжнародне співробітництво Рахункової палати.

Міжнародне співробітництво $є$ важливим інструментом інституційного розвитку Рахункової палати та посилення спроможності виконувати покладені на неї функції вищого органу аудиту України. Як у межах міжнародних фахових організацій, так і в межах двостороннього співробітництва міжнародне співробітництво забезпечує обмін досвідом і знаннями з метою удосконалення зовнішнього державного аудиту, а також проведення міжнародних координованих паралельних аудитів за важливими для України напрямами. ми, як:

Рахункова палата здійснює міжнародне співробітництво за такими основними напряма-

- розвиток двостороннього і багатостороннього співробітництва з ВОА іноземних країн;

- співробітництво з Європейською організацією вищих органів аудиту (EUROSAI) та Міжнародною організацією вищих органів аудиту (INTOSAI);

- забезпечення діяльності робочої групи EUROSAI з аудиту коштів, виділених на попередження та ліквідацію наслідків катастроф, під головуванням Рахункової палати;

- участь у робочих і спеціальних групах EUROSAI (з аудиту навколишнього середовища; інформаційних технологій та аудиту муніципалітетів);

- участь у робочих групах INTOSAI (з аудиту навколишнього середовища; державного боргу; з питань боротьби з корупцією та відмиванням коштів);

- участь у роботі інших регіональних об'єднань ВОА;

- співпраця з міжнародними організаціями й участь у проектах і програмах міжнародної технічної допомоги;

- участь Рахункової палати в аудитах програм, що фінансуються за рахунок коштів Європейського Союзу;

- організація та проведення міжнародних координованих паралельних аудитів за участі членів Робочої групи з аудиту коштів, виділених на попередження та ліквідацію наслідків катастроф [8].

Рахунковою палатою підписані двосторонні угоди про співробітництво з вищими органами аудиту 27 країн [9], зокрема: Угода про співробітництво між Рахунковою палатою України і Рахунковою палатою Азербайджанської Республіки від 04 травня 2006 р. [10], Угода про співробітництво між Рахунковою палатою України та Національним аудиторським офісом 
Швеції від 4 грудня 2008 р. [11], Угода про співробітництво між Рахунковою палатою України та Рахунковим судом Федеративної Республіки Німеччина від 25 грудня 2009 р. [12], Угода про співробітництво між Рахунковою палатою України та Національним аудиторським офісом Китайської Народної Республіки від 23 жовтня 2013 р. [13], Угода про співробітництво між Рахунковою палатою України та Державним контролем Естонії від 11 червня 2018 р. [14], Угода про співробітництво між Рахунковою палатою України та Рахунковою палатою Республіки Албанії від 14 червня 2018 р. [15].

3-поміж багатосторонніх міжнародних договорів доцільно виокремити: Декларацію про партнерство і співпрацю між Вищим офісом аудиту Польщі, Державним офісом аудиту Грузії, Аудиторським судом Республіки Молдова та Рахунковою палатою України від 23 лютого 2015 р. [16] та Меморандум про взаєморозуміння між Рахунковою палатою Азербайджанської Республіки, Комітетом державного контролю Республіки Білорусь, Державним аудиторським офісом Грузії та Рахунковою палатою України від 11 липня 2019 р. [17].

Відповідно до п. 50.2. Регламенту Рахункової палати міжнародні угоди про співробітництво згідно з рішеннями Рахункової палати укладаються Рахунковою палатою з відповідними органами іноземних держав і міжнародними організаціями, до компетенції яких належать питання фінансово-економічного контролю державних фінансів, та інституціями міжнародної технічної допомоги.

Важливе значення серед проектів і програм міжнародної технічної допомоги за участю Рахункової палати має Проект міжнародної технічної допомоги «Розбудова адміністративних потужностей у сфері державних фінансів в Україні» № 2013.2296.5, з метою реалізації якого було підписано ряд міжнародних договорів із питань міжнародного співробітництва Рахункової палати як вищого органу аудиту України у проектах і програмах міжнародної технічної допомоги, зокрема: Меморандум про співробітництво між Німецьким товариством міжнародного співробітництва (GIZ) ГмбX і Рахунковою палатою України від 25 квітня 2014 р. [18], Протокол № 1 про внесення змін до Меморандуму про співробітництво між Німецьким товариством міжнародного співробітництва (GIZ) ГмбX і Рахунковою палатою України від 25 квітня 2014 р. від 05 липня 2016 р. [19], Лист про наміри між Рахунковою палатою і Німецьким товариством міжнародного співробітництва (GIZ) ГмбХ від 30 січня 2019 р. [20].

3. Внутрішній контроль у Рахунковій палаті.

Згідно зі ст. 1 Закону України «Про Рахункову палату» встановлено, що Рахункова палата від імені Верховної Ради України здійснює контроль за надходженням коштів до Державного бюджету України та їх використанням.

Відповідно до ч. 4 ст. 363 Закону України «Про аудит фінансової звітності та аудиторську діяльність» [21] державний фінансовий аудит здійснюється Рахунковою палатою й органами державного фінансового контролю відповідно до закону.

Головним об'єктом контрольної діяльності Рахункової палати є державний бюджет: щодо нього застосовується як наступний, так і попередній контроль, проводиться перевірка своєчасності виконання за обсягами, за структурою та цільовим призначенням, обгрунтованістю дохідних і видаткових статей, ефективністю та доцільністю витрат державних коштів [22, с. 10].

Посадові особи Рахункової палати є державними службовцями, і на них поширюється дія Закону України «Про державну службу» [23].

Враховуючи вищенаведене, 3 метою уникнення посадовими особами Рахункової палати корупційних дій, безвідповідального ставлення до своєї роботи чи інших непрофесійних дій надзвичайно важливо забезпечити ефективний внутрішній контроль у Рахунковій палаті.

На думку Л.Г. Годованої, внутрішній контроль - це система контрольних процедур, план організації та методи управління об'єктом із метою ефективного проведення бізнесу, захисту активів, запобігання помилок, акуратності облікових перевірок і своєчасного представлення фінансової інформації. Контроль - це процес, що забезпечує досягнення цілей організації. Дуже часто внутрішній контроль ототожнюють із внутрішнім аудитом [24].

Основним нормативно-правовим актом, який регламентує внутрішній контроль у Рахунковій палаті, $\epsilon$ «Порядок організації та здійснення внутрішнього контролю в Рахунковій палаті» [25] (далі - Порядок), затверджений наказом Голови Рахункової палати від 15 серпня 2019 р. № 51. Він визначає механізм організації та функціонування внутрішнього контролю й управління ризиками в Рахунковій палаті та самостійних структурних підрозділах апарату Рахункової палати. Метою розробки Порядку є забезпечення організації та здійснення внутрішнього контролю в Рахунковій палаті. 
Згідно 3 п. 1.4. Порядку внутрішній контроль - це комплекс заходів, що застосовуються Головою Рахункової палати для забезпечення дотримання законності й ефективності використання бюджетних коштів, досягнення результатів відповідно до встановленої мети, завдань, планів щодо діяльності Рахункової палати. Система внутрішнього контролю - впроваджені Головою Рахункової палати політика, правила і заходи, які забезпечують функціонування, взаємозв'язок і підтримку всіх елементів внутрішнього контролю і спрямовані на досягнення визначених мети (місії), стратегічних та інших цілей, завдань, планів і вимог щодо діяльності Рахункової палати.

Відповідно до п. 1.7. Порядку система внутрішнього контролю в Рахунковій палаті складається з таких елементів, як: внутрішнє середовище; управління ризиками; заходи контролю; інформація та комунікація (інформаційний і комунікаційний обмін); моніторинг. Елементи внутрішнього контролю взаємопов'язані, стосуються всієї діяльності та фінансових і нефінансових процесів у Рахунковій палаті.

Висновки. Отже, поняття «функції Рахункової палати як вищого органу аудиту України» можна визначити як основні напрями впливу Рахункової палати як вищого органу аудиту України на поведінку суб' єктів правовідносин із метою організації діяльності та здійснення повноважень Рахункової палати.

Можна виокремити такі функції Рахункової палати: здійснення заходів державного зовнішнього фінансового контролю (аудиту), міжнародне співробітництво, внутрішній контроль у Рахунковій палаті.

Перспективи подальших наукових досліджень у цьому напрямі полягають у порівняльно-правовому аналізі функцій Рахункової палати та вищих органів аудиту країн-членів СС, принципів діяльності Рахункової палати, адміністративно-правового статусу Рахункової палати.

Отже, у статті охарактеризовано проблематику функцій Рахункової палати як вищого органу аудиту України.

\section{Список використаних джерел:}

1. Resolution adopted by the General Assembly № 69/228 (2014), "Promoting and fostering the efficiency, accountability, effectiveness and transparency of public administration by strengthening supreme audit institutions". URL: http://www.un.org/es/comun/docs/index.asp?symbol=A/ RES/69/228\&referer=/spanish/\&Lang=E (дата звернення: 21.09.2019). C. 104-109.

2. Койчева О.С. Проблеми реалізації функцій Рахункової палати. Наше право. 2014. № 7.

3. Савченко Л.А. Правові основи фінансового контролю : навчальний посібник. Київ : Юрінком Інтер, 2008. 504 с.

4. Гриценко О.I. Рахункова палата: державно-правова природа, сучасний стан, перспективи розвитку. Запоріжжя : Видавництво ВАТ «Мотор Січ», 2004. $138 \mathrm{c}$.

5. Про Рахункову палату : Закон України від 2 липня 2015 р. Відомості Верховної Ради України. 2015. № 36. Ст. 360.

6. Андреев А.Г. Правовые основы финансового контроля. Финансы. 2009. № 12. С. 62-64.

7. Регламент Рахункової палати, затверджений рішенням Рахункової палати від 28 серпня 2018 p № 22-7. URL: https://rp.gov.ua/upload-files/About/RegulatoryDoc/arp_1_new.pdf (дата звернення: 22.09.2019).

8. Міжнародне співробітництво. URL: https://rp.gov.ua/IntCooperation/ General/ (дата звернення 22.09.2019).

9. Угоди про співробітництво. URL: https://rp.gov.ua/IntCooperation/ Agreements/ (дата звернення 22.09.2019).

10. Угода про співробітництво між Рахунковою палатою України і Рахунковою палатою Азербайджанської Республіки від 04 травня 2006 p. URL: https://rp.gov.ua/upload-files/ IntCooperation/Agreements/2006_Azerbaijan_ukr.pdf (дата звернення: 22.09.2019).

11. Угода про співробітництво між Рахунковою палатою України та Національним аудиторським офісом Швеції від 4 грудня 2008. URL: https://rp.gov.ua/upload-files/IntCooperation/ Agreements/2008Sweden_ukr.pdf (дата звернення 22.09.2019).

12. Угода про співробітництво між Рахунковою палатою України та Рахунковим судом Федеративної Республіки Німеччини від 25 грудня 2009 p. URL: https://rp.gov.ua/upload-files/ IntCooperation/Agreements/2009Germany__ukr.pdf (дата звернення: 23.09.2019).

13. Угода про співробітництво між Рахунковою палатою України та Національним аудиторським офісом Китайської Народної Республіки від 23 жовтня 2013 p. URL: https://rp.gov.ua/ upload-files/IntCooperation/ Agreements/2013China_Ukr.pdf (дата звернення: 23.09.2019). 
14. Угода про співробітництво між Рахунковою палатою України та Державним контролем Естонії від 11 червня 2018 p. URL: https://rp.gov.ua/upload-files/IntCooperation/Agreements/ Estonia RP Ukr.pdf (дата звернення 23.09.2019).

15. Угода про співробітництво між Рахунковою палатою України та Рахунковою палатою Республіки Албанії від 14 червня 2018 р. URL: https://rp.gov.ua/upload-files/IntCooperation/ Agreements/Albania_RP_Ukr.pdf (дата звернення: 24.09.2019).

16. Partnershipand cooperation declaration among The Supreme Audit Office of Poland, The State Audit Office of Georgia, the Court of Accounts of the Republic of Moldova and the Accounting Chamber of Ukrainefrom 23 February 2015. URL: https://rp.gov.ua/upload-files/IntCooperation/ Agreements/ 2015CoopDecl4SAO.pdf (дата звернення: 24.09.2019).

17. Меморандум про взаєморозуміння між Рахунковою палатою Азербайджанської Республіки, Комітетом державного контролю Республіки Білорусь, Державним аудиторським офісом Грузії та Рахунковою палатою України від 24 вересня 2019 p. URL: https://rp.gov.ua/upload-files/ IntCooperation/Agreements/2019Memorandum_Ukr.pdf (дата звернення: 24.09.2019).

18. Меморандум про співробітництво між Німецьким товариством міжнародного співробітництва (GIZ) ГмбX та Рахунковою палатою України від 25 квітня 2014 p. URL: https://rp.gov. ua/upload-files/IntCooperation/ Agreements/2014GIZ_RP_UkrEng.pdf (дата звернення: 24.09.2019).

19. Протокол № 1 про внесення змін до Меморандуму про співробітництво між Німецьким товариством міжнародного співробітництва (GIZ) ГмбХ та Рахунковою палатою України від 25 квітня 2014 р. від 05 липня 2016 р. URL: https://rp.gov.ua/upload-files/IntCooperation/ Agreements/2016GIZ_RP_UkrEng.pdf (дата звернення: 24.09.2019).

20. Лист про наміри між Рахунковою палатою і Німецьким товариством міжнародного співробітництва (GIZ) ГмбХ від 30 січня 2019 p. URL:https://rp.gov.ua/upload-files/IntCooperation/ Agreements/2019GIZ_RP_UkrEng.pdf (дата звернення: 25.09.2019).

21. Про аудит фінансової звітності та аудиторську діяльність : Закон України від 21 грудня 2017 р. Відомості Верховної Ради Украӥни. 2018. № 9. Ст. 50.

22. Крутевич М.М. Конституційно-правові основи діяльності Рахункової палати в Україні. Окремі аспекти. Юридична наука. 2015. № 7. С. 7-13.

23. Про державну службу : Закон України від 10 грудня 2015 р. Відомості Верховної Ради України. 2016. № 4. Ст. 43.

24. Годована Л.Г. Внутрішній контроль та внутрішній аудит, схожість і відмінність. URL: http://eztuir.ztu.edu.ua/bitstream/handle/123456789/139/ 21.pdf?sequence=1 (дата звернення: 25.09.2019).

25. Порядок організації та здійснення внутрішнього контролю в Рахунковій палаті : затверджений наказом Голови Рахункової палати від 15 серпня 2019 p. № 51. URL: https://rp.gov.ua/ upload-files/About/ RegulatoryDoc/Por_vn_kontr_RP.pdf (дата звернення: 25.09.2019). 